\title{
Species' Geographic Distributions Through Time: Playing Catch-up with Changing Climates
}

\author{
A. Townsend Peterson • Bruce S. Lieberman
}

Published online: 2 March 2012

(C) Springer Science+Business Media, LLC 2012

\begin{abstract}
Species' ranges are often treated as a fixed characteristic, rather than a fluid, ever-changing manifestation of their ecological requirements and dispersal abilities. Paleontologists generally have had a better appreciation of the changeable nature of species' ranges than neontologists, but each perspective can improve by appreciating the other. Here, we provide an overview of paleontological and neontological perspectives on species' geographic distributions, focusing on what can be learned about historical variations in distributions. In particular, we focus on enriching the field of phylogeography with a more explicit view of geography, taking into account variation through time in the geographic distribution of different environments, effectively integrating information from the fossil record, molecular genetics, and paleoclimatology. The cross-disciplinary view that would result offers novel perspectives on biogeography and macroevolution.
\end{abstract}

Keywords Paleontology · Neontology · Geographic distribution . Climate change

\section{Introduction}

Geographic distributions of species are frequently treated as fixed across space, particularly as regards biodiversity conservation efforts (e.g., Collar et al. 1994). The spatial

\footnotetext{
A. T. Peterson $(\bowtie) \cdot$ B. S. Lieberman

Biodiversity Institute, University of Kansas,

Lawrence, KS 66045, USA

e-mail: town@ku.edu

B. S. Lieberman

Department of Geology, University of Kansas, Lawrence, KS 66045, USA
}

dynamics that lie behind current ranges of species, however, have often gone underappreciated by neontologists and have been left largely to the consideration of paleontologists (see review by Davis and Shaw 2001). Although not without exceptions (e.g., Wells 1983), most of current ecology and evolutionary biology has not pondered the dynamic nature of species' distributions in sufficient detail. This disconnect in point of view has perhaps blinded neontologists to the diversity of geographic and environmental contexts that current species diversity has experienced over its history and points out an excellent opportunity for interaction between paleontologists and neontologists to clarify several important research questions.

The fields that should be most conscious of these dynamics are molecular systematics and phylogeography. That is, these fields focus attention on population history over geography, as reconstructed by detailed analyses of molecular genetic data. As such, these fields should pay attention more closely to the historical sequence of range dynamics - nonetheless, at least until recently, phylogeography has not taken its "geography" base seriously enough (Peterson 2009), particularly in light of rampant blind application of molecular clock methodologies to complex geographic and historical questions (Peterson 2007). The result is a field that seriously needs to broaden its vision of the complex set of interactions between history, geography, and environmental conditions, if it is to achieve a truly synthetic perspective.

Paleontologists have traditionally had a much more dynamic view of species' distributions through time and through space (e.g., Coope 1979; Davis 1986; Foster et al. 1990; Lieberman 2000b). Given that the paleontological record tends to be a longitudinal view (i.e., through time) of biological diversity, paleontologists have perforce paid much more attention to the dynamic nature of geographic distributions. Of particular interest, and a phenomenon 
documented in particularly good detail, are the distributional shifts that accompanied Pleistocene glaciations in many species, some of which are still extant (Martin and Harrell 1957; Lomolino et al. 1989; Roy et al. 1995). The prePlio-Pleistocene fossil record does not always display the completeness and density of the youngest geological epochs. Still, similar types of distributional changes have been documented for species in the more distant geological past.

More recently, researchers exploring a novel set of tools have marshaled new sets of information to reflect on these issues, based on the concept of the ecological niche as the suite of environmental conditions within which a species is able to maintain populations without immigrational subsidy (Grinnell 1917, 1924; Soberón and Peterson 2005; Soberón 2007, 2010). In effect, the "niche" is a stable distribution-environment relationship that constrains species' geographic potential, although the degree to which niches characterize species versus the populations that make them up (Peterson and Holt 2003) can certainly be debated, given the universal possibility of local adaptation in broadly distributed species (Kawecki and Ebert 2004). Specifically, using ecological niche modeling (ENM) approaches (sometimes mis-termed "species distribution modeling" approaches; Peterson 2006), researchers have established a series of points that have considerable empirical support: (1) that species' ecological niche characteristics are generally conserved over at least moderate periods of evolutionary time (Peterson et al. 1999; Peterson 2011), (2) that species' ecological niches constitute consistent and stable constraints on their distributional potential (Araújo and Rahbek 2006; Araújo et al. 2009), and (3) that dynamics of environments across complex landscapes present significant challenges to species for persistence (Peterson et al. 2002; Pearson and Dawson 2003); a basic explanation of ENM ideas is presented in Fig. 1. With these three insights in hand, numerous research groups have been exploring the possibility of reconstructing paleodistributions of species based on niche model projections

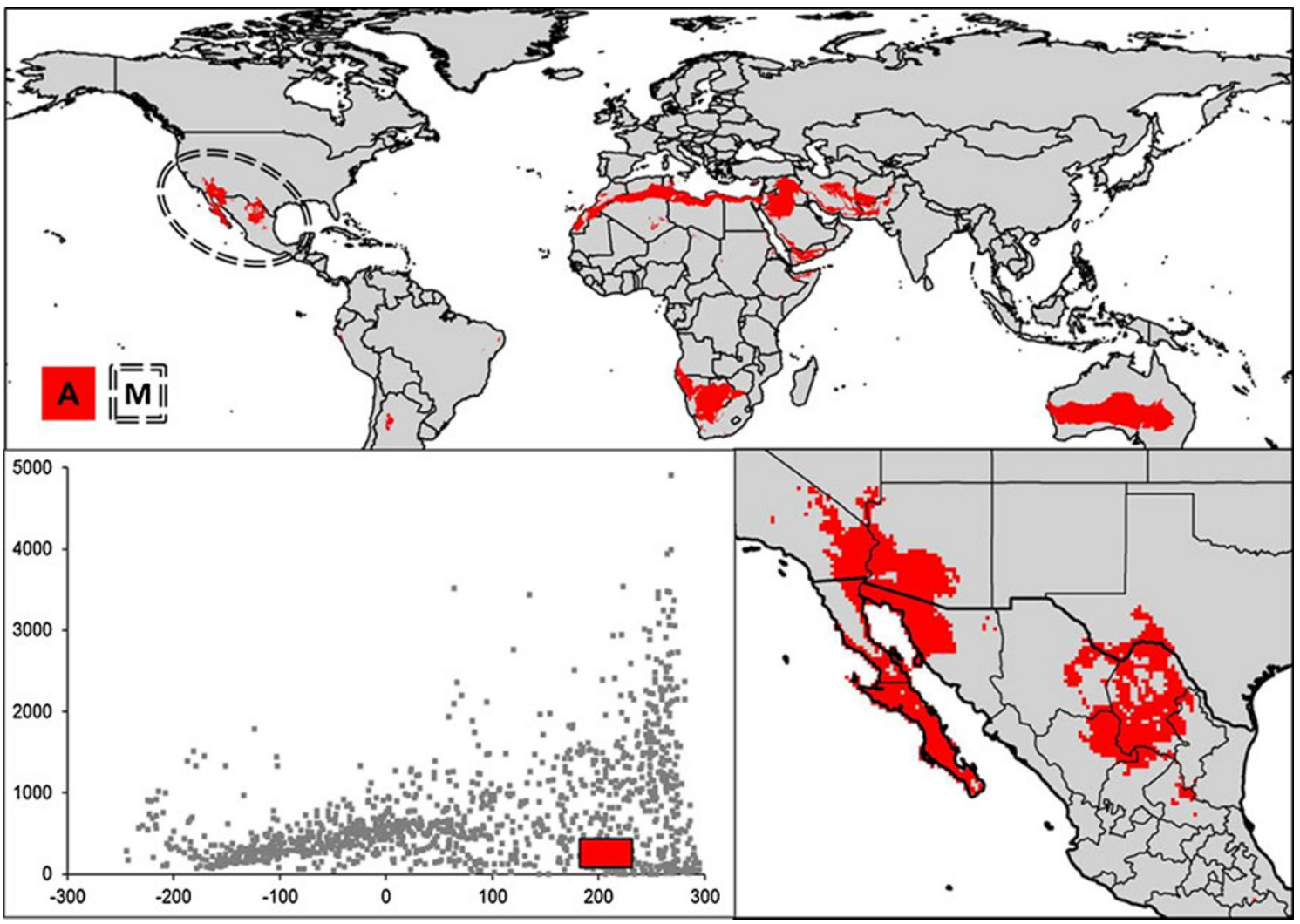

Fig. 1 Summary of basic ideas of ecological niche modeling. An ecological niche defined in two environmental dimensions (for simplicity of illustration) is shown in the lower left panel-gray points represent the broader "background" of environments, while the red rectangle indicates the hypothetical niche (termed $A$; E. Saupe et al., in preparation). The upper panel shows the global footprint of this niche, corresponding more or less to relatively mesic subtropical deserts. The area that is accessible to the species is termed $M$ and is shown as a broken double line. The inset at the lower right then shows the portion of the broader footprint that is accessible to the species and that makes up its actual geographic distribution (were this to be a real species). Niche modeling would take known occurrences from the geographic distribution of the species, obtain their environmental values, and contrast environmental values of known occurrences with those of the background to produce a "niche model." The niche model can then be used to probe broader areas, such as the whole world or such as conditions present in another time period, to estimate potential distributional areas 
over paleoclimate reconstructions (e.g., Martínez-Meyer et al. 2004; Peterson et al. 2004; Bonaccorso et al. 2006; MartínezMeyer and Peterson 2006; Banks et al. 2007, 2008; Peterson and Nyári 2007; Waltari et al. 2007; Nogués-Bravo et al. 2008; Banks et al. 2009; Buckley et al. 2009; Jakob et al. 2009; Marske et al. 2009; Shepard and Burbrink 2009; Nyári et al. 2010; Premoli et al. 2010; Varela et al. 2010). Insights from this new field, however, have been limited by the too-frequent lack of fossil material, as well as by "molecular dating" of lineages that frequently leaves much rigor to be desired.

This paper aims to provide an up-to-date overview of the state of knowledge of the dynamics of species' geographic distributions over the past three to five million years. That is, we provide a panorama of what is - and is not - known about range shifts from the Pliocene through the Pleistocene and up to the present; special emphasis is paid to terrestrial systems because ENM approaches to this issue have primarily concentrated there. The objective, most fundamentally, is to set the stage for a broad integration of paleoclimatology, paleontology, and biogeography. More specifically, we hope that this review will further the process of thinking outside of our disciplinary "boxes," thus leading to better levels of synthesis and integration across fields, especially between paleontology and neontology in general and paleobiogeography and biogeography in particular.

\section{Paleoenvironmental Dynamics}

The past several millions of years clearly represent an environmentally distinctive time period. Relative to earth history, this period on average represents an unusually cold interval: Indeed, the climatic regime has been broadly characterized as being in an "icehouse" state. Not only were average conditions unusually cold but also numerous, dramatic, and regular climatic oscillations between warm and cold temperatures, produced by orbitally controlled phenomena termed Milankovitch cycles, occurred during this period. For instance, during warm intervals, hippopotami basked in the Thames River, and during cold intervals, ice sheets progressed as far south as Kansas. These climatic changes profoundly altered many species' geographic distributions: The aforementioned example involving hippos is just one example; studies that have considered Pleistocene fossils explicitly have also analyzed beetles (Coope 1979), trees (Davis 1986), and mammals (Graham 1986). Further, migrations associated with changing climates caused changes in population genetic structure, variably through both fragmenting and merging populations, which has been the product of at least three processes: (1) changes in landform (e.g., via uplift or subsidence), (2) climatic changes, and (3) changes in connectivity of coastal areas owing to changing sea levels (which in turn depend in large part on global climate). These regional and global processes are often cited as driving major features of the biodiversity realm (Avise 2000; Lomolino et al. 2005).

Geological processes are generally slow, such that large-scale topographic evolution over the lifespans of most species $\left(10^{4}-10^{6}\right.$ years, perhaps?) might be seen as fairly unlikely to have influenced major features of species' distributions. However, such changes have been documented to have had significant effects on species' distributions and phylogenetic patterns in the distant geological past, for example, in the Cambrian and the Devonian (Lieberman and Eldredge 1996; Lieberman 2000b, 2003; Meert and Lieberman 2004; Rode and Lieberman 2005). Even since the Late Pleistocene, some Earth regions have shown substantial uplift or subsidence (Harff et al. 2007), and major Earth features, such as the Andean mountain chain, have arisen relatively recently (Hartley 2003), creating important new distributional opportunities and barriers for species and biotas. The relevance of these major changes to the distributional biology of species, of course, depends critically on the age of the species and specific lineage in question.

Certainly of more direct relevance to present-day species' distributional biology has been climate change. The Pleistocene-covering approximately the past $1.5-2.5$ million years-was characterized by dramatic shifts from conditions rather similar to those of the present day (Otto-Bliesner et al. 2006) to much colder conditions (Dansgaard et al. 1993). The effect of these fluctuations on biodiversity began to be appreciated thanks to the detailed documentation of past vegetation types provided by Neotoma packrat middens (Lanner and Van Devender 1981; Wells 1983). Pleistocene climatic shifts also figured very prominently in theories for the diversification of the Amazon Basin (Haffer 1974), and these ideas have been adopted quite broadly (e.g., Church et al. 2003), although they have also been controversial (Bush 1994).

Coastline shifts associated with changing sea levels are another physical environmental dimension that has been cited extensively as structuring distributions of biotas (Heaney 1991). The phenomenon occurs because different global temperature regimes tie up different amounts of water in ice caps and glaciers, meaning that sea level can be quite a bit lower during cold intervals (Lambeck and Chappell 2001) —indeed, Pleistocene glaciations lowered global sea levels by $80-120$ meters during glacial periods. These rather dramatic changes in sea level left present-day shallow seas as dry land during glacial periods - particularly notable examples from a present-day perspective include the connection of the British Isles to the European mainland, linkage of New Guinea to northern Australia, and connection 
of the Falkland/Malvinas Islands to the Argentine coast. In deeper time, especially in the Devonian, cycles of sea-level change have been shown to have had profound impacts on biogeographic and phylogenetic patterns (Lieberman and Eldredge 1996; Rode and Lieberman 2005; Abe and Lieberman 2009).

One region where coastline effects associated with Pleistocene sea-level changes have been especially dramatic is in Southeast Asia, in the Sunda Shelf region (Malaysia and Indonesia) and the nearby Philippines. These regions are geographically complex: in some cases, distantly separated islands are separated by continental shelves, whereas closely situated islands may be divided by very deep straits. In this region, broad and relatively shallow seas separating present-day islands became land connections during globally cool periods (Voris 2000). Pleistocene warm-cool cycles then would have produced cycles of connection and isolation, which could have driven speciation pulseshowever, although numerous early studies were interpreted as fitting well with this phenomenon (Peterson and Heaney 1993; Voris 2000; Heaney et al. 2005), more detailed recent studies have found exceptions, suggesting that simple connection or isolation of land masses may not be sufficient to structure biodiversity (Esselstyn and Brown 2009; Esselstyn et al. 2010).

The summary of potential paleoenvironmental dynamics and their effects on species' distributions just presented should serve only to impress the reader of the enormous complexity involved in these processes. Areas suitable for species to inhabit are structured-i.e., connected or isolated-by complex suites of barriers that may be "hard," such as an ocean for a terrestrial organism, or that may be softer, such as less suitable climatic conditions or less attractive vegetation cover. These barriers are not static, but dynamic, through time, even the "hard" ones - that is, they change in shape and size and effectiveness through time, sometimes over long time periods and sometimes quite abruptly. Finally, different species respond in distinct ways to different types of barriers, such that each may have its own, unique history, or that history may be congruent across several species.

\section{Paleontology and the Past Few Million Years}

As already mentioned, during the Pleistocene, globally cool periods (and associated glaciations) and warm interglacial periods alternated, and it might be expected that the species in the extant biota should have been profoundly influenced by these changes. Indeed, either they evolved as part of speciation events that transpired during (and were associated with) the climatic oscillations or if they evolved earlier and persisted through this interval of profound change, they should have at least experienced numerous episodes of population aggregation and disassociation in the face of the climatic changes. One real advantage of studying the Pleistocene (and Pliocene), as opposed to earlier time periods, is that we have an exceptionally detailed knowledge of climate during this time interval. This knowledge comes from a variety of sources, including pollen and foraminiferan distributional records, and geochemical information collected from sources including packrat middens and marine microfossil shells. It has even been possible to reconstruct detailed climate models for these time periods in the marine realm, as with the PRISM (Dowsett et al. 2010) and HadOCC (Collins et al. 2011) initiatives. Further, carbon dating allows us to date Pleistocene climatic events and faunal changes with exceptional precision. Of course, caution must be exercised, especially when the distributional records of still-modern species found in the fossil record are used to adduce ancient climate conditions because this process involves uniformitarian assumptions about species' environmental parameters that may not necessarily be valid. However, in light of considerable evidence for conservatism in coarse-resolution ecological niche characteristics of moderate periods of evolutionary time (Peterson 2011), we do not view these issues as being especially problematic. Indeed, they point out the value of the approach being advocated here: using quantitative methods to study the niches of a plethora of species in a statistical framework and in the context of detailed climate models.

\section{Information from Molecular Genetics}

As should be clear from the preceding section, while paleontological data are the only direct information source about past distributions of species, they will forever be limited by the incomplete nature imposed by the vagaries of preservation. As a consequence, the paleontological record will always be incomplete (just as all sources of scientific information are by their very nature incomplete), and other sources of information must be sought. These sources, while certainly less direct and clear, have the opportunity to provide some insight into past distributional patterns for a broader diversity of species. One important source comes from phylogeographic studies of spatial patterns of molecular genetic differentiation among extant lineages across their geographic distributions (Avise 2000).

A first question that is addressed in phylogeographic studies is the basic existence of population genetic structure across the distribution of a species, which likely reflects past spatial isolation of populations. Some species indeed do not show such structure (Avise 2009), likely as a result of recent origin in a single population. Testing this basic hypothesis offers a first insight regarding past distributions 
of a given lineage- - finding significant population structure leads to a next set of hypothesis tests regarding the nature of that structure (Knowles 2006).

Coalescent approaches offer a next series of inferences regarding the species in question, using statistical properties of the distribution of alleles of genes among populations of a species and estimates of their origins from single ancestral copies (Knowles 2006). Coalescent approaches offer the opportunity to reconstruct historical patterns and trends in population size and population subdivision. With advances in the ease with which molecular data can be obtained in quantity (e.g., large population samples, multiple genes, long sequences), this field has become a burgeoning area of inquiry, with hundreds of papers published yearly. The general conclusion - at least for vertebrates and certainly not without exception - has been that, although much of existing genetic structure springs from the Pleistocene, older (pre-Pleistocene) events are discernable as well (e.g., Rodríguez-Sánchez et al. 2010). Earlier and simpler, noncoalescent approaches generally pushed structuring events farther back into the past, antedating the Pleistocene (Klicka and Zink 1997). However, more powerful and refined coalescent-based approaches typically recover the signature of Pleistocene events first and foremost (McCormack et al. 2010) [further, the beginning of the Pleistocene has recently been extended back nearly a million years (Gradstein et al. 2005; Riccardi 2009), such that some speciation events once defined as pre-Pleistocene now need to be re-defined as occurring within the Pleistocene].

These molecular-genetic approaches to understanding historical biogeography, however, are not without limitations. First and most simply, at least the early approaches employed in phylogeographic studies for estimating splitting times (i.e., dating isolation events) have been overly simple and without attention paid to variation in evolutionary rates (Peterson 2007). More recent methods incorporate variation among lineages in evolutionary rates (Drummond and Rambaut 2007), but even these dates should nonetheless be considered preliminary and in need of independent confirmation. Of course, it is possible to make phylogeographic inferences without recourse to a molecular clock. For instance, Lieberman (2000a) documented how a freshwater mollusk species had genetic structure signaling Pliocene events and sought congruence between biogeographic patterns and geological events that could be assigned to specific time intervals.

A more fundamental concern is that phylogeographic approaches have focused largely on the "phylo" part and less on the "geography" (Peterson 2009). That is, while phylogeographic approaches have much to offer in detecting the existence of historical population isolation, they have had less success in associating this isolation with real geographic features of present or past landscapes. This inferential gap has led to subjective "story-telling" when it comes to interpreting the past population isolation in geographic terms, limiting the strength of the inferences about the past geography of species and speciation. The new methods described below offer the real possibility of concrete reconstruction of which environmental and geographic factors were likely responsible for particular isolation and lineage-splitting events.

In very recent years, the growing fields of landscape genetics and statistical phylogeography (Holderegger and Wagner 2008) have emerged, presenting considerable promise in filling these gaps, although not without growing pains of understanding appropriate methodologies, and seeking appropriate conceptual frameworks (Wang 2010). In particular, recent efforts to link phylogeographic approaches with geographic inferences derived from ENM hold considerable promise: These advances are treated below, under "Synthesis."

\section{Niche Modeling Insights}

ENM holds great promise for development of spatially explicit hypotheses on the distributions of species through time. However, this promise is subject to several caveats, not the least of which is simply the young and preliminary nature of the field and of its applications to such questions. In this sense, a powerful set of methods is only now being developed, key sets of data are only beginning to be assembled and refined, and analytical and interpretive frameworks are only beginning to be explored.

Caveats The basics of ENM approaches are as follows: "Models" are derived from nonrandom associations between known occurrences of species and digital map-based summaries of environmental characteristics, such as maps of climatic parameters. A diversity of algorithms for identifying and quantifying these nonrandom associations has been developed and has seen many comparative tests (e.g., Elith et al. 2006; Graham et al. 2007; Guisan et al. 2007; Ortega-Huerta and Peterson 2008). Nonetheless, the youth of the field is clear if one considers the heterogeneity of standards, methodologies and terminologies (Lobo et al. 2008; Peterson et al. 2008; Soberón 2010).

Regarding use of these methodologies to understand present and past distributions of species, numerous assumptions and limitations are clear, as follows. A first, and very important, assumption of these approaches is that ecological niches are conservative enough over time that they can serve as a basis for predictions about the distributional potential of species. This topic, raised in several early papers (Huntley et al. 1989; Ricklefs and 
Latham 1992; Peterson et al. 1999), has become a topic of considerable debate (Broennimann et al. 2007; Fitzpatrick et al. 2007; Wiens 2008; Medley 2010). However, the debate turns out to be largely a consequence of imprecise definition and consequent misunderstanding of key concepts (e.g., Graham et al. 2004; Fitzpatrick et al. 2008), rather than true conflict of ideas, as has been made clear by recent insights (Warren et al. 2008) and an extensive literature review (Peterson 2011). The emerging view is that ecological niches - at least those defined in terms of the so-called scenopoetic variables such as climate-are indeed quite surprisingly stable through at least moderate periods of evolutionary time. Dudei and Stigall (2010), in a fascinating study, considered what happens to the niches of species over longer, geological time scales.

A still-more-fundamental issue is whether species' distributions are structured and constrained by climatic factors, for without this causal association, niche model projections through time and onto different climate scenarios would be rather meaningless. A recent publication (Beale et al. 2008) argued that most of a large sample of bird species across Europe does not have distributions that are constrained by climatic factors. This conclusion, however, was based on analyses fraught with complications (Araújo et al. 2009; Peterson et al. 2009), particularly as regards exclusion of distributional limits of the species in question from the area of analysis. A study developed in parallel to the original one, but in a geographic arena that holds much more species endemism, yielded opposite results (Jiménez-Valverde et al. 2010), suggesting that the original work was flawed, probably in large part owing to artificial delimitation of the study area to western Europe.

Perhaps much more crippling for niche model applications to questions of historical geography of species are concerns about data quality. Despite major community efforts, such as the Paleoclimate Modeling Intercomparison Project (http://pmip.lsce.ipsl.fr/), terrestrial paleoclimatic data remain rather difficult to come by (at least on global scales) and are presently limited to the Last Glacial Maximum (20,000 years ago) and the Last Interglacial (135,000 years ago), which greatly constrains the analyses that can be developed. Hand in hand with this concern goes the spatial and temporal resolution of those data that are available, which is inevitably coarse. Finally, occurrence data from the present and back through the paleontological record are needed to permit testing and validation of model predictions but are only partially digitized and thereby not easily and efficiently available to scientists.

Insights Several studies have used ENM to study species' biogeography in deep time (e.g., Stigall Rode and Lieberman 2005; Stigall and Lieberman 2006; Maguire and Stigall 2009; Dudei and Stigall 2010). For more recent periods, the emerging suite of studies that have explored projections onto Pleistocene conditions of ecological niches of extant species to identify Pleistocene potential distributional areas (Martínez-Meyer et al. 2004; Peterson et al. 2004; Bonaccorso et al. 2006; Martínez-Meyer and Peterson 2006; Banks et al. 2007, 2008, 2009; Peterson and Nyári 2007; Waltari et al. 2007; Nogués-Bravo et al. 2008; Buckley et al. 2009; Jakob et al. 2009; Marske et al. 2009; Shepard and Burbrink 2009; Nyári et al. 2010; Premoli et al. 2010; Varela et al. 2010) has begun to perceive some generalities that are quite interesting. For instance, several species in subtropical or temperate regions appear to have had the opportunity to retain much of their present-day distributional area back through globally cold periods like the last glaciation (Peterson et al. 2004; Jakob et al. 2009), such that Pleistocene climate changes may not have caused universal, broad range shifts among huge numbers of species, but rather fluctuations in the relative suitability and continuity of their ranges. As an illustration, Fig. 2 provides a view of reconstructed stability among high-latitude populations of the wild barley genus Hordeum in South America.

A second insight has been that species' responses to climate change will have greater horizontal manifestations (i.e., range shifts) in different regions. That is, because gradients in environmental characteristics are much broader and shallower in flatland areas than in montane areas, species have to move greater distances to "keep up" with their suitable distributional areas in flatlands than in mountains (Peterson 2003). Figure 3 shows an illustration of these differences in comparisons of birds of the Great Plains and of the adjacent Rocky Mountains. This tendency toward greater range stability in montane regions has interesting implications for generation of diversity, speciation, and other longer-term phenomena.

Finally, these analyses are beginning to cast doubt on some insights from molecular analyses. That is, until recently, molecular insights, such as dating of speciation events from molecular clock analyses (in itself a dubious enterprise: see, e.g., Pagel et al. 2006), were the only information available other than what is at times in the terrestrial realm and for some taxa a sparse paleontological record. What is more, because molecular clocks are frequently calibrated based on fossil information, insights from these two sources of information are generally nonindependent but give the appearance of independent confirmation. Nonetheless, very preliminary analyses using paleoclimatic projections of niche models are casting doubt on issues that had been "decided" based on molecular data, such as the pre-Pleistocene nature of vertebrate speciation in the Amazon Basin (Bonaccorso et al. 2006; Peterson and Nyári 2007) and the exceptional age of the Sahara Desert as a biogeographic barrier 
Fig. 2 Present-day (dark gray and black) and past (light gray and black) distribution models of three Hordeum species in southern South America, calculated with GARP on the basis of present-day occurrence points (white dots) for the species. The past potential distribution areas are during the Last Glacial Maximum (about 21,000 years ago), and represent a consensus between two different global climate models. Apart from inland Patagonia and Tierra del Fuego, the models infer stable potential distributional areas of the Hordeum species throughout their present-day distributions since the Last Glacial Maximum. Reproduced with permission from Jakob et al. (2009)

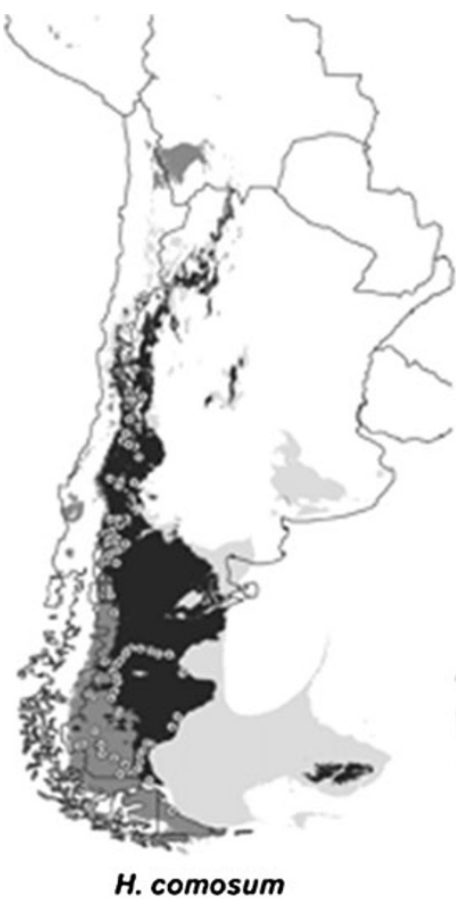

H. comosum

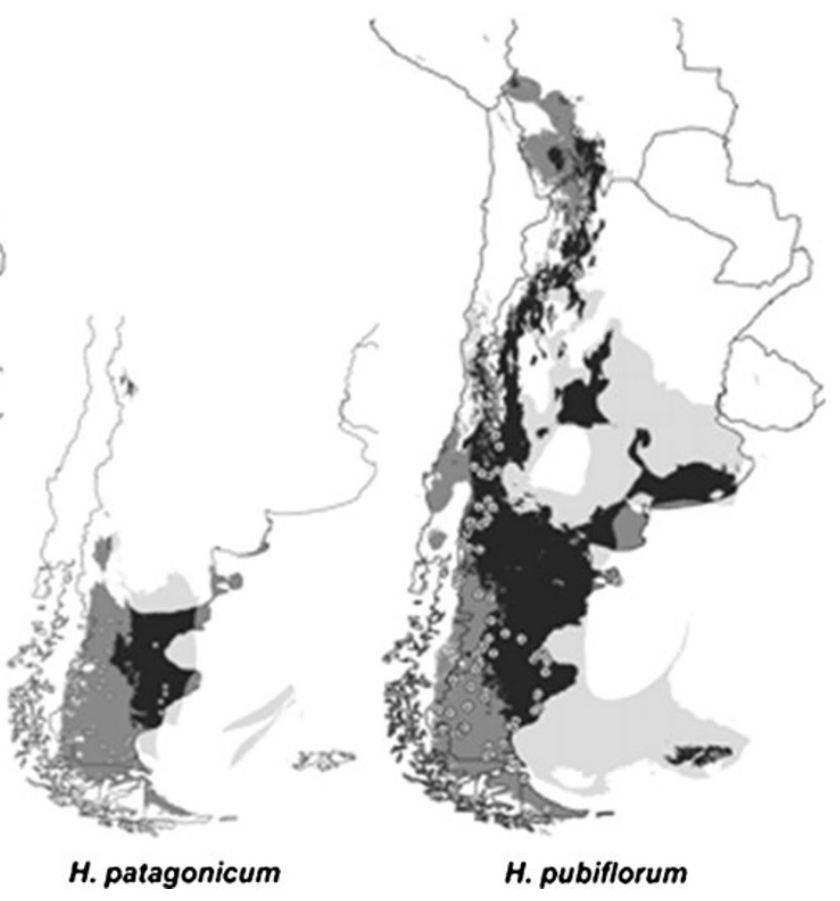

(Nyári et al. 2010). Figure 4 illustrates one such effort to reconstruct historical (Pleistocene Last Glacial Maximum) ranges of species, for Schiffornis turdinus, a bird species of the Neotropical lowlands (Peterson and Nyári 2007). Many studies of this sort will soon appear with broader application of these techniques, increasingly in tandem with molecular analyses (Knowles et al. 2007).

\section{Synthesis}

The possibilities for a deeper understanding of species' geography back through evolutionary time are exciting. Although the field of phylogeography is still rather young (Avise 2000), it stands to improve considerably with incorporation of a broader swath of information and evidence (Peterson 2009). Put quite simply, phylogeographic studies in recent years have relied on the potentially rich information available from molecular studies (e.g., dating of splitting events, metrics of population history, etc.), but to the point of not weighting sufficiently other potential sources of insight. The result is a picture of phylogeography that emphasizes the "phylo" much more than the "geography," and as a consequence, we lose some information that could otherwise be of considerable advantage to scientists.

The emerging field of ENM and related approaches brings quantitative, real-world geography to the question of understanding species' geographic distributions. In essence, occurrence data and paleoclimatic estimates that are independent of the molecular and fossil information can be brought to bear on the same questions, which may corroborate previous ideas or may suggest more robust alternatives. For instance, recent molecular studies of the high-latitude barley genus Hordeum in South America indicated a refugial historical population structure, in contrast to the "recent expansion" molecular signature that might have been expected in light of postglacial population expansion; this idea was corroborated by niche model projections that indicated persistence of suitable conditions across the range of the species in question through at least the late Pleistocene (Jakob et al. 2009). In other cases, the multiple sets of information may contradict one another (e.g., Nyári et al. 2010), prompting reexamination of the strength of evidence behind each viewpoint.

\section{The Way Forward}

Important steps in the right direction have already been taken, yet challenges remain. First, more powerful approaches are under development that link paleontological evidence with paleoenvironmental data in a nichemodeling framework. This advance includes initial explorations (Stigall and Lieberman 2006; Stigall 2008) that proved concepts. Now, more detailed applications to a variety of paleontological hypotheses are appearing in the literature (Dudei and Stigall 2010; Myers and Lieberman 2011; Walls and Stigall 2011).

Greater integration between paleontological and neontological information would enrich many studies substantially, although it does face obstacles and in some cases may 

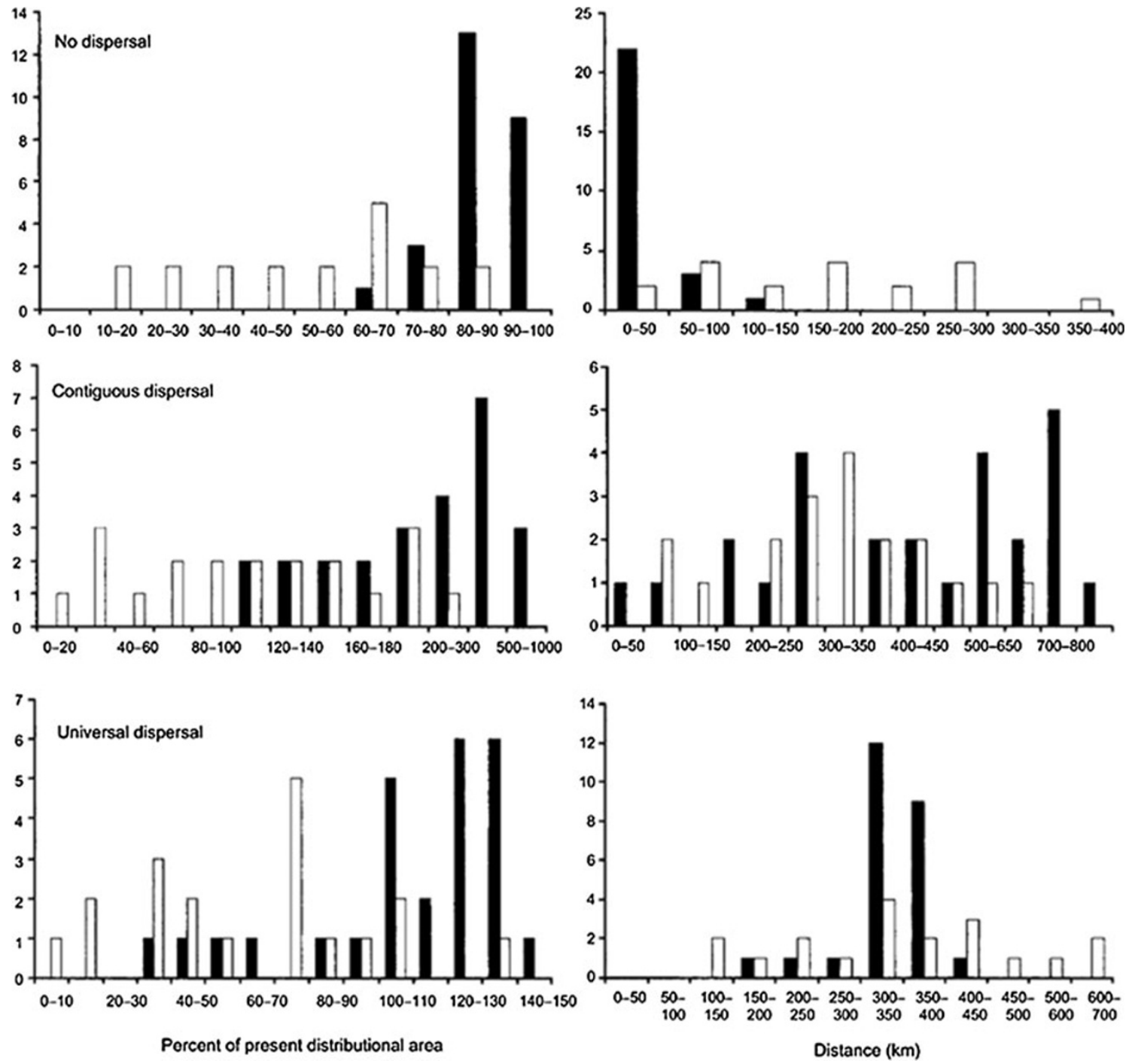

Fig. 3 Projected change in potential distributional areas (left column, expressed as percent of present distributional area) and projected distance that range centroids would shift (right column), as a result of modeled climate change processes. Results are separated for montane (black) and flatlands (white) species and for three

never be possible. For instance, for some taxa (principally those that are non-skeletonized), reliable paleontological occurrence records may never exist: consider the paucity of fossil information available for any study of biogeography of soft-bodied invertebrates. In other groups, even when fossils are known, precise taxonomic assignments may be challenging-such groups may not be the best subjects for biogeographic (and phylogeographic) studies anyway, particularly if the groups under study are ancient (Lieberman $2000 \mathrm{~b}, 2002$ ). The older a group is, the more time is available, offering a greater potential for episodes of range expansion or population extirpation to have occurred. These events might have influenced a group's biogeography and evolution profoundly, but if its earlier evolutionary history was not appreciated or was unknown to paleontologists, they would assumptions regarding dispersal ability (no dispersal, contiguous dispersal, universal dispersal). Note the contrasts between montane and flatlands species in the degree of change of suitable area and position of suitable areas. Reproduced with permission from Peterson (2003)

be impossible to discern. Even when paleontological occurrence records are available, they only define minimum geographic ranges, as the fossil record is unlikely to capture completely the entire geographic range of the species (parallel issues also affect neontological occurrence records, but they will generally be much less severe).

A final issue is that niche modeling studies depend perforce not only on availability of distributional records but also on linking those records to detailed environmental datasets. For the modern biota, comprehensive environmental datasets exist, comprising diverse variables at fine spatial and temporal resolutions. As we go back in geological time, fewer environmental variables can be sampled and the precision with which they can be estimated drops rapidly. Temporal precision also lessens dramatically: except in the most 
Present

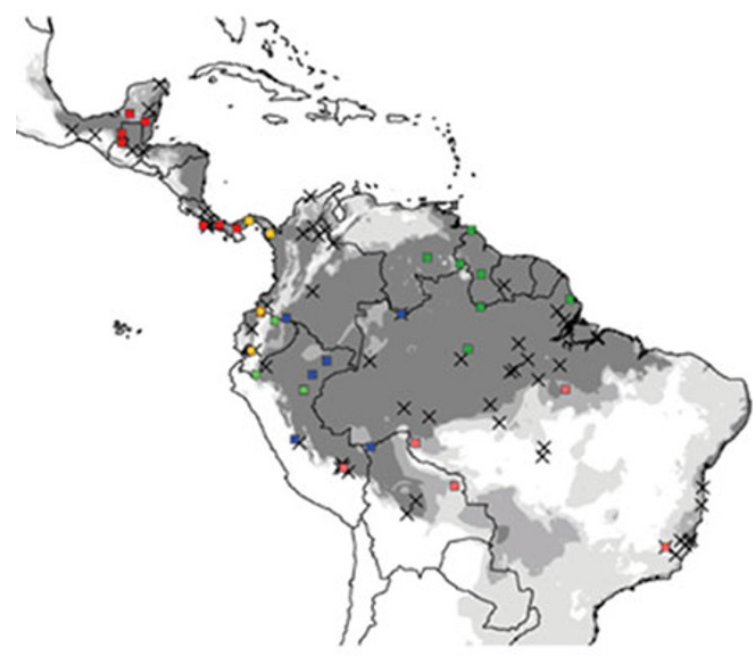

CCSM

(Community Climate System Model)

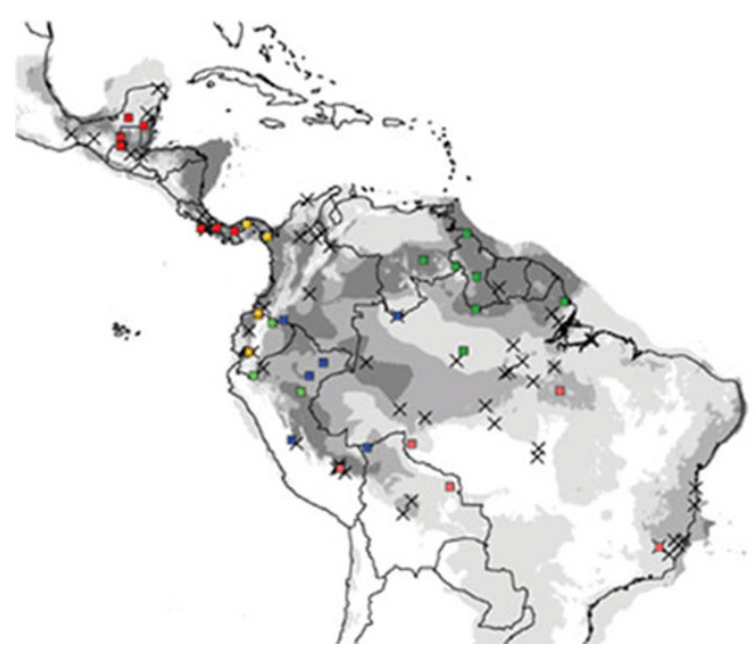

Fig. 4 Ecological niche model estimates of present-day and Last Glacial Maximum potential distributional areas, the latter under two different general circulation model estimates, for $S$. turdinus. Also shown are sample points for niche model development $(X s)$ and

pristine paleolacustrine records, indicators of paleoclimate on annual scales is complete folly; instead, we must be content to estimate environmental parameters over broader periods $\left(10^{3}-10^{5}\right.$ years $)$. We suspect that such limitations are lessened by the longer time intervals under consideration, averaging out the imprecision and assessing larger magnitudes of environmental change. Certainly, including more data (adding fossil information to neontological studies and data on extant taxa to paleontological studies) always seems like a better path forward: Plenty of room exists in studies of biogeography, evolution, and the history of life, to include both paleontology and neontology.

Another important step forward is in the development of methodological frameworks for integrating molecular and

\section{Legend}

\section{Model predictions}

\section{all models predicting absence \\ 1 - 5 models predicting presence \\ 6-9 models predicting presence \\ all models predicting presence}

\section{Phylogroups}

1. Mexico to Western Panama

2.Eastern Panama

3. Western Ecuador lowlands

4. cis-Andean foothills

5. Amazon Basin headwaters

6. Southeast Amazon and Atlantic Forest

7.Guyanan Shield

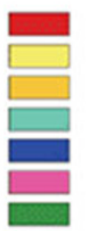

(Model for Interdisciplinary Research on Climate)

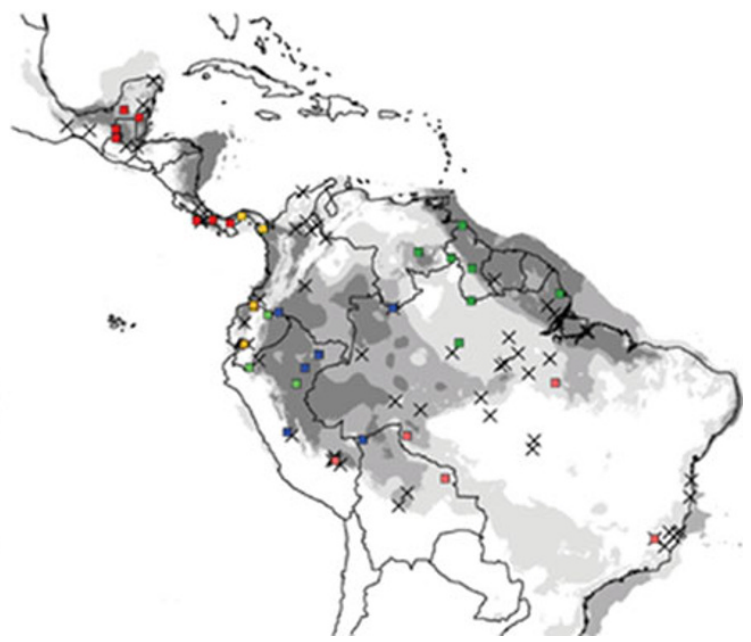

sampling localities for genetic data (squares, with different colors indicating distinct molecular phylogroups). Reproduced with permission from Peterson and Nyári (2007)

niche-based evidence. Papers by Carstens and Richards (2007), Knowles et al. (2007), and Richards et al. (2007) presented the basis for new and more synthetic ideas and approaches. This promise is now translating into rich research results, with many exciting and novel papers appearing each month (Chan et al. 2011; Lim et al. 2011). Such rapid methodological development suggests a rich future for such studies, in which deep insights into past geographies of species become available.

\section{The Big Questions}

This overview has emphasized the dynamic nature of the geographic distributions of species. It, nonetheless, remains 
woefully incomplete, as the answers to many fundamental questions remain largely out of reach. These questions have been the focus of research in biogeography since the origins of the field and yet have not been answered powerfully. A few of these "big" questions are outlined in the next paragraphs.

The role of Pleistocene climatic fluctuations in generating current biodiversity is poorly understood. Considerable early speculation pointed to a dominant role (Darwin 1859; Haffer 1974), while numerous recent analyses have pointed to a much more minor role (Klicka and Zink 1997). Still, the results of the more recent analyses may not hold up well once better calibrations and molecular dating approaches are used (Peterson 2007). Most recently, several analyses have used more refined approaches to dating speciation events and have found indeed that many speciation events do date to the Pleistocene, likely in response to the dramatic climate changes occurring in that period (McCormack et al. 2010). As a consequence, the predominance of Pleistocene speciation remains an open question, and the entire enterprise of reconstructing rates of speciation and extinction through time appears to be complex and still under development (Stadler 2011a, b).

The equilibrium versus nonequilibrium nature of species' geographic distributions has not as yet been established. That is, species' ranges might respond closely to climatic fluctuations and track appropriate conditions closely, or they might "put up with" the average conditions and "squeak through" the extremes, but the balance is not yet clear. The question is basically that of whether dispersal abilities of species allow them to track their climatic optima or whether the rapidity of the climatic changes outstrips species' ability to disperse, colonize, and establish populations, but the answer is not clear. The manner in which climatic changes in the distant geological past triggered invasions, extinctions, and evolution and the relevance of these phenomena to future biotic responses has also not always been considered, though counterexamples do exist (Vermeij 1978; McGhee 1996; Rode and Lieberman 2004; Stigall 2010).

Finally, the lessons of the past could have much to teach us about the present and future. Species' responses to current anthropogenic climate changes are only beginning to be appreciated (e.g., Parmesan 1996; Parmesan et al. 1999, 2004; Peterson and Martínez-Meyer 2009) and only for a small sample of species for which before-and-after information is available. Looking forward, after early speculation (Peters and Darling 1985; Dobson et al. 1989), model predictions regarding biodiversity in future climate states have often been preliminary or even overinterpreted (e.g., Thomas et al. 2004). Scenarios based on more realistic linked models of climate change and dispersal are only beginning to appear (Gotelli et al. 2009), leaving much to be understood and discovered.

\section{References}

Abe FR, Lieberman BS. The nature of evolutionary radiations: a case study involving Devonian trilobites. Evol Biol. 2009;36:225-34.

Araújo MB, Rahbek C. How does climate change affect biodiversity? Science. 2006;313:1396-7.

Araújo MB, Thuiller W, Yoccoz NG. Reopening the climate envelope reveals macroscale associations with climate in European birds. Proc Natl Acad Sci USA. 2009;106:E45-6.

Avise JC. Phylogeography: the history and formation of species. 3rd ed. Cambridge: Harvard University Press; 2000.

Avise JC. Phylogeography: retrospect and prospect. J Biogeogr. 2009;36:3-15.

Banks WE, d'Errico F, Peterson AT, Vanhaeren M, Kageyama M, Sepulchre P, Ramstein G, Jost A, Lunt D. Human ecological niches and ranges during the LGM in Europe derived from an application of eco-cultural niche modeling. J Archaeol Sci. 2007;35:481-91.

Banks WE, d'Errico F, Peterson AT, Kageyama M, Columbeau G. Reconstructing ecological niches and geographic distributions of caribou (Rangifer tarandus) and red deer (Cervus elaphus) during the Last Glacial Maximum. Quat Sci Rev. 2008;27:2568-75.

Banks WE, d'Errico F, Peterson AT, Kageyama M, Sima A, SánchezGoñi M-F. Neanderthal extinction by competitive exclusion. PLoS ONE. 2009;3:e3972.

Beale CM, Lennon JJ, Gimona A. Opening the climate envelope reveals no macroscale associations with climate in European birds. Proc Natl Acad Sci USA. 2008;105:14908-12.

Bonaccorso E, Koch I, Peterson AT. Pleistocene fragmentation of Amazon species' ranges. Divers Distrib. 2006;12:157-64.

Broennimann O, Treier UA, Müller-Schärer H, Thuiller W, Peterson AT, Guisan A. Evidence of climatic niche shift during biological invasion. Ecol Lett. 2007;10:701-9.

Buckley TR, Marske KA, Attanayake D. Identifying glacial refugia in a geographic parthenogen using palaeoclimate modelling and phylogeography: the New Zealand stick insect Argosarchus horridus (White). Mol Ecol. 2009;18:4650-63.

Bush MB. Amazonian speciation: a necessarily complex model. J Biogeogr. 1994;21:5-17.

Carstens BC, Richards CL. Integrating coalescent and ecological niche modeling in comparative phylogeography. Evolution. 2007;61:1439-54.

Chan LM, Brown JL, Yoder AD. Integrating statistical genetic and geospatial methods brings new power to phylogeography. Mol Phylogenet Evol. 2011;59:523-37.

Church SA, Kraus JM, Mitchell JC, Church DR, Taylor DR. Evidence for multiple Pleistocene refugia in the postglacial expansion of the eastern tiger salamander, Ambystoma tigrinum tigrinum. Evolution. 2003;57:372-83.

Collar NJ, Crosby MJ, Stattersfield AJ. Birds to watch 2. The world list of threatened birds. Cambridge: Bird Life International; 1994.

Collins WJ, Bellouin N, Doutriaux-Boucher M, Gedney N, Halloran P, Hinton T, Hughes J, Jones CD, Joshi M, Liddicoat S, Martin G, O'Connor F, Rae J, Senior C, Sitch S, Totterdell I, Wiltshire A, Woodward S. Development and evaluation of an Earth-system model-HadGEM2. Geosci Model Dev Discuss. 2011;4:997-1062.

Coope GR. Late Cenozoic Coleoptera: evolution, biogeography, and ecology. Annu Rev Ecol Syst. 1979;10:247-67.

Dansgaard W, Johnsen SJ, Clausen HB, Dahl-Jensen D, Gundestrup NS, Hammer CU, Hvidberg CS, Steffensen JP, Sveinbjörnsdóttir $\mathrm{AE}$, Jouzel J, Bond GC. Evidence for general instability of past climate from a $250 \mathrm{kyr}$ ice-core record. Nature. 1993;264:218-20.

Darwin C. On the origin of species by means of natural selection, or the preservation of favoured races in the struggle for life. London: Murray; 1859. 
Davis MB. Climatic instability, time lags, and community disequilibrium. In: Diamond J, Case TJ, editors. Community ecology. New York: Harper and Row; 1986. p. 269-84.

Davis MB, Shaw RG. Range shifts and adaptive responses to Quaternary climate change. Science. 2001;292:673-9.

Dobson A, Jolly A, Rubenstein D. The greenhouse effect and biological diversity. Trends Ecol Evol. 1989;4:64-8.

Dowsett HJ, Robinson M, Hayward A, Salzmann U, Hill D, Sohl L, Chandler M, Williams M, Foley K, Stoll D. The PRISM3D paleoenvironmental reconstruction. Stratigraphy. 2010;7:123-40.

Drummond A, Rambaut A. BEAST: Bayesian evolutionary analysis by sampling trees. BMC Evol Biol. 2007;7:214.

Dudei NL, Stigall AL. Using ecological niche modeling to assess biogeographic and niche response of brachiopod species to the Richmondian Invasion (Late Ordovician) in the Cincinnati Arch. Palaeogeogr Palaeoclimatol Palaeoecol. 2010;296:28-43.

Elith J, Graham CH, Anderson RP, Dudik M, Ferrier S, Guisan A, Hijmans RJ, Huettman F, Leathwick JR, Lehmann A, Li J, Lohmann LG, Loiselle BA, Manion G, Moritz C, Nakamura M, Nakazawa Y, Overton JM, Peterson AT, Phillips SJ, Richardson K, Scachetti-Pereira R, Schapire RE, Soberón J, Williams SE, Wisz MS, Zimmermann NE. Novel methods improve prediction of species' distributions from occurrence data. Ecography. 2006;29:129-51.

Esselstyn JA, Brown RM. The role of repeated sea-level fluctuations in the generation of shrew (Soricidae: Crocidura) diversity in the Philippine Archipelago. Mol Phylogenet Evol. 2009;53:171-81.

Esselstyn JA, Oliveros CH, Moyle RG, Peterson AT, McGuire JA, Brown RM. Integrating phylogenetic and taxonomic evidence illuminates complex biogeographic patterns along Huxley's modification of Wallace's Line. J Biogeogr. 2010;37:2054-66.

Fitzpatrick MC, Weltzin JF, Sanders NJ, Dunn RR. The biogeography of prediction error: why does the introduced range of the fire ant overpredict its native range? Glob Ecol Biogeogr. 2007;16:24-33.

Fitzpatrick MC, Dunn RR, Sanders NJ. Datasets matter, but so do evolution and ecology: a response to Peterson and Nakazawa. Glob Ecol Biogeogr. 2008;17:562-5.

Foster DR, Schoonmaker PK, Pickett STA. Insights from paleoecology to community ecology. Trends Ecol Evol. 1990;5:119-22.

Gotelli NJ, Anderson MJ, Arita HT, Chao A, Colwell RK, Connolly SR, Currie DJ, Dunn RR, Graves GR, Green JL, Grytnes J-A, Jiang Y-H, Jetz W, Kathleen Lyons S, McCain CM, Magurran AE, Rahbek C, Rangel TFLVB, Soberón J, Webb CO, Willig MR. Patterns and causes of species richness: a general simulation model for macroecology. Ecol Lett. 2009;12:873-86.

Gradstein FM, Ogg JG, Smith AG, editors. A geologic time scale 2004. Cambridge: Cambridge University Press; 2005.

Graham RW. Response of mammalian communities to environmental changes during the late Quaternary. In: Diamond J, Case TJ, editors. Community ecology. New York: Harper and Row; 1986. p. 300-13.

Graham CH, Elith J, Hijmans R, Guisan A, Peterson AT, Loiselle BA, NCEAS Species Distribution Modeling Group. The influence of spatial errors in species occurrence data used in distribution models. J Appl Ecol. 2007;45:239-47.

Graham CH, Ron SR, Santos JC, Schneider CJ, Moritz C. Integrating phylogenetics and environmental niche models to explore speciation mechanisms in dendrobatid frogs. Evolution. 2004;58:1781-93.

Grinnell J. Field tests of theories concerning distributional control. Am Nat. 1917;51:115-28.

Grinnell J. Geography and evolution. Ecology. 1924;5:225-9.

Guisan A, Graham CH, Elith J, Huettman F, NCEAS Species Distribution Modelling Group. Sensitivity of predictive species distribution models to change in grain size. Divers Distrib. 2007;13:332-40.

Haffer J. Avian speciation in tropical South America, with a systematic survey of the toucans (Ramphastidae) and jacamars (Galbulidae). Publ Nuttall Ornithol Club. 1974;14:1-390.
Harff J, Hay WW, Tetzlaff DM, editors. Coastline changes: interrelation of climate and geological processes. Boulder: Geological Society of America; 2007.

Hartley AJ. Andean uplift and climate change. J Geol Soc. 2003;160:7-10.

Heaney LR. A synopsis of climatic and vegetational change in Southeast Asia. Clim Chang. 1991;19:53-61.

Heaney LR, Walsh Jr JS, Peterson AT. The roles of geological history and colonization abilities in genetic differentiation between mammalian populations in the Philippine archipelago. J Biogeogr. 2005;32:229-47.

Holderegger R, Wagner HH. Landscape genetics. Bioscience. 2008;58:199-207.

Huntley B, Bartlein PJ, Prentice IC. Climatic control of the distribution and abundance of beech (Fagus L.) in Europe and North America. J Biogeogr. 1989;16:551-60.

Jakob SS, Martinez-Meyer E, Blattner FR. Phylogeographic analyses and paleodistribution modeling indicate Pleistocene in situ survival of Hordeum species (Poaceae) in southern Patagonia without genetic or spatial restriction. Mol Biol Evol. 2009;26:907-23.

Jiménez-Valverde A, Barve N, Lira-Noriega A, Maher SP, Nakazawa Y, Papeș M, Soberón J, Sukumaran J, Peterson AT. Dominant climate influences on North American bird distributions. Glob Ecol Biogeogr. 2010;20:114-8.

Kawecki TJ, Ebert D. Conceptual issues in local adaptation. Ecol Lett. 2004;7:1225-41.

Klicka J, Zink RM. The importance of recent ice ages in speciation: a failed paradigm. Science. 1997;277:1666-9.

Knowles LL. Statistical phylogeography. Annu Rev Ecol Evol Syst. 2006;40:593-612.

Knowles LL, Carstens BC, Keat ML. Coupling genetic and ecologicalniche models to examine how past population distributions contribute to divergence. Curr Biol. 2007;17:940-6.

Lambeck K, Chappell J. Sea level change through the last glacial cycle. Science. 2001;292:679-86.

Lanner RM, Van Devender TR. Late Pleistocene piñon pines in the Chihuahuan Desert. Quat Res. 1981;15:278-90.

Lieberman BS. Applying molecular phylogeography to test paleoecological hypotheses: a case study involving Amblema plicata (Mollusca, Unionidae). In: Allmon WD, Bottjer D, editors. Evolutionary paleoecology. New York: Columbia University Press; 2000a. p. 83-103.

Lieberman BS. Paleobiogeography: using fossils to study global change, plate tectonics, and evolution. New York: Plenum; $2000 \mathrm{~b}$.

Lieberman BS. Biogeography with and without the fossil record. Palaeogeogr Palaeoclimatol Palaeoecol. 2002;178:39-52.

Lieberman BS. Paleobiogeography: the relevance of fossils to biogeography. Annu Rev Ecol Syst. 2003;34:51-69.

Lieberman BS, Eldredge N. Trilobite biogeography in the Middle Devonian: geological processes and analytical methods. Paleobiology. 1996;22:66-79.

Lim HC, Rahman MA, Lim SLH, Moyle RG, Sheldon FH. Revisiting Wallace's haunt: coalescent simulations and comparative niche modeling reveal historical mechanisms that promoted avian population divergence in the Malay Archipelago. Evolution. 2011;65:321-34.

Lobo JM, Jiménez-Valverde A, Real R. AUC: a misleading measure of the performance of predictive distribution models. Glob Ecol Biogeogr. 2008; 17:145-51.

Lomolino MV, Brown JH, Davis R. Island biogeography of montane forest mammals in the American Southwest. Ecology. 1989;70:180-94.

Lomolino MV, Riddle BR, Brown JH. Biogeography. 3rd ed. Sunderland: Sinauer Associates; 2005.

Maguire KC, Stigall AL. Distribution of fossil horses in the Great Plains during the Miocene and Pliocene: an ecological niche modeling approach. Paleobiology. 2009;35:597-611. 
Marske KA, Leschen RAB, Barker GM, Buckley TR. Phylogeography and ecological niche modelling implicate coastal refugia and trans-alpine dispersal of a New Zealand fungus beetle. Mol Ecol. 2009; 18:5126-42.

Martin PS, Harrell BE. The Pleistocene history of temperate biotas in Mexico and eastern United States. Ecology. 1957;38:468-80.

Martínez-Meyer E, Peterson AT. Conservatism of ecological niche characteristics in North American plant species over the Pleistocene-to-Recent transition. J Biogeogr. 2006;33:1779-89.

Martínez-Meyer E, Peterson AT, Hargrove WW. Ecological niches as stable distributional constraints on mammal species, with implications for Pleistocene extinctions and climate change projections for biodiversity. Glob Ecol Biogeogr. 2004;13:30514.

McCormack JE, Delaney KS, Peterson AT. Calibrating divergence times on species trees versus gene trees: implications for speciation history of Aphelocoma jays. Evolution. 2010;65:184-202.

McGhee Jr GR. The Late Devonian mass extinction. New York: Columbia University Press; 1996.

Medley KA. Niche shifts during the global invasion of the Asian tiger mosquito, Aedes albopictus Skuse (Culicidae), revealed by reciprocal distribution models. Glob Ecol Biogeogr. 2010;19:122-33.

Meert JG, Lieberman BS. A palaeomagnetic and palaeobiogeographic perspective on latest Neoproterozoic and early Cambrian tectonic events. J Geol Soc Lond. 2004;161:1-11.

Myers CE, Lieberman BS. Sharks that pass in the night: using geographical information systems to investigate competition in the Cretaceous Western Interior Seaway. Proc R Soc B. 2011;278:681-89.

Nogués-Bravo D, Rodríguez J, Hortal J, Batra P, Araújo MB. Climate change, humans, and the extinction of the wooly mammoth. PLoS Biol. 2008;6:e79.

Nyári ÁS, Peterson AT, Rathbun GB. Late Pleistocene potential distribution of the North African elephant-shrew Elephantulus rozeti (Mammalia: Macroscelidea). Afr Zool. 2010;45:330-9.

Ortega-Huerta MA, Peterson AT. Modeling ecological niches and predicting geographic distributions: a test of six presence-only methods. Rev Mex de la Biodiversidad. 2008;79:205-16.

Otto-Bliesner BL, Marshall SJ, Overpeck JT, Miller GH, Hu A, CAPE Last Interglacial Project members. Simulating Arctic climate warmth and icefield retreat in the Last Interglaciation. Science. 2006;311:1751-3.

Pagel M, Venditti C, Meade A. Large punctuational contribution of speciation to evolutionary divergence at the molecular level. Science. 2006;314:119-21.

Parmesan C. Climate and species' range. Nature. 1996;382:765-6.

Parmesan C, Ryrholm N, Stefanescu C, Hill JK, Thomas CD, Descimon H, Huntley B, Kaila L, Kullberg J, Tammaru T, Tennent J, Thomas JA, Warren M. Poleward shift of butterfly species' ranges associated with regional warming. Nature. 1999;399:579-83.

Parmesan C, Gaines S, González L, Kaufman DM, Kingsolver J, Peterson AT, Sagarin R. Empirical perspectives on species borders: from traditional biogeography to global change. Oikos. 2004;108:58-75.

Pearson RG, Dawson TP. Predicting the impacts of climate change on the distribution of species: are bioclimate envelope models useful? Glob Ecol Biogeogr. 2003;12:361-71.

Peters RL, Darling JDS. The greenhouse effect and nature reserves. Bioscience. 1985;35:707-17.

Peterson AT. Projected climate change effects on Rocky Mountain and Great Plains birds: generalities of biodiversity consequences. Glob Chang Biol. 2003;9:647-55.

Peterson AT. Uses and requirements of ecological niche models and related distributional models. Biodivers Inform. 2006;3:59-72.

Peterson AT. Application of molecular clocks in ornithology revisited. J Avian Biol. 2007;37:541-4.
Peterson AT. Phylogeography is not enough: the need for multiple lines of evidence. Front Biogeogr. 2009;1:19-25.

Peterson AT. Ecological niche conservatism: a time-structured review of evidence. J Biogeogr. 2011;38:817-27.

Peterson AT, Heaney LR. Genetic differentiation in Philippine bats of the genera Cynopterus and Haplonycteris. Biol J Linn Soc. 1993;49:203-18.

Peterson AT, Holt RD. Niche differentiation in Mexican birds: using point occurrences to detect ecological innovation. Ecol Lett. 2003;6:774-82.

Peterson AT, Martínez-Meyer E. Pervasive poleward shifts among North American bird species. Biodiversity. 2009;9:14-6.

Peterson AT, Nyári Á. Ecological niche conservatism and Pleistocene refugia in the thrush-like mourner, Schiffornis sp., in the Neotropics. Evolution. 2007;62-I:173-83.

Peterson AT, Soberón J, Sánchez-Cordero V. Conservatism of ecological niches in evolutionary time. Science. 1999;285:1265-7.

Peterson AT, Ortega-Huerta MA, Bartley J, Sanchez-Cordero V, Soberon J, Buddemeier RH, Stockwell DRB. Future projections for Mexican faunas under global climate change scenarios. Nature. 2002;416:626-9.

Peterson AT, Martínez-Meyer E, González-Salazar C. Reconstructing the Pleistocene geography of the Aphelocoma jays (Corvidae). Divers Distrib. 2004;10:237-46.

Peterson AT, Papeș M, Soberón J. Rethinking receiver operating characteristic analysis applications in ecological niche modelling. Ecol Model. 2008;213:63-72.

Peterson AT, Barve N, Bini LM, Diniz-Filho JA, Jiménez-Valverde A, Lira-Noriega A, Lobo JM, Maher S, Marco Jr PD, MartínezMeyer E, Nakazawa Y, Soberón J. The climate envelope may not be empty. Proc Natl Acad Sci USA. 2009;106:E47.

Premoli AC, Mathiasen P, Kitzberger T. Southern-most Nothofagus trees enduring ice ages: genetic evidence and ecological niche retrodiction reveal high latitude $\left(54^{\circ} \mathrm{S}\right)$ glacial refugia. Palaeogeogr Palaeoclimatol Palaeoecol. 2010;298:247-56.

Riccardi AC. IUGS ratified ICS recommendation on redefinition of Pleistocene and formal definition of base of Quaternary [resolution]. Reston: International Union of Geological Sciences; 2009.

Richards CL, Carstens BC, Knowles LL. Distribution modelling and statistical phylogeography: an integrative framework for generating and testing alternative biogeographical hypotheses. J Biogeogr. 2007;34:1833-45.

Ricklefs RE, Latham RE. Intercontinental correlation of geographical ranges suggests stasis in ecological traits of relict genera of temperate perennial herbs. Am Nat. 1992;139:1305-21.

Rode A, Lieberman BS. Using GIS to study the biogeography of the Late Devonian biodiversity crisis. Palaeogeogr Palaeoclimatol Palaeoecol. 2004;211:345-59.

Rode AL, Lieberman BS. Integrating biogeography and evolution using phylogenetics and PaleoGIS: a case study involving Devonian crustaceans. J Paleontol. 2005;79:267-76.

Rodríguez-Sánchez F, Hampe A, Jordano P, Arroyo J. Past tree range dynamics in the Iberian Peninsula inferred through phylogeography and palaeodistribution modelling: a review. Rev Palaeobot Palynol. 2010;162:507-21.

Roy K, Jablonsk D, Valentine JW. Thermally anomalous assemblages revisited: patterns in the extraprovincial latitudinal range shifts of Pleistocene marine mollusks. Geology. 1995;23:1071-4.

Shepard DB, Burbrink FT. Phylogeographic and demographic effects of Pleistocene climatic fluctuations in a montane salamander, Plethodon fourchensis. Mol Ecol. 2009;18:2243-62.

Soberón J. Grinnellian and Eltonian niches and geographic distributions of species. Ecol Lett. 2007;10:1115-23.

Soberón J. Niche and area of distribution modeling: a population ecology perspective. Ecography. 2010;33:159-67. 
Soberón J, Peterson AT. Interpretation of models of fundamental ecological niches and species' distributional areas. Biodivers Inform. 2005;2:1-10.

Stadler T. Inferring speciation and extinction processes from extant species data. Proc Natl Acad Sci USA. 2011a;108:16145-6.

Stadler T. Mammalian phylogeny reveals recent diversification rate shifts. Proc Natl Acad Sci USA. 2011b;108:6187-92.

Stigall AL. Tracking species in space and time: assessing the relationships between paleobiogeography, paleoecology, and macroevolution. In: Kelley PH, Bambach RK, editors. From evolution to geobiology: research questions driving paleontology at the start of a new century. Boulder: Paleontological Society; 2008. p. $227-42$.

Stigall AL. Invasive species and biodiversity crises: testing the link in the Late Devonian. PLoS ONE. 2010;5:e15584.

Stigall Rode AL, Lieberman BS. Using environmental niche modelling to study the Late Devonian biodiversity crisis. In: Over DJ, Morrow JR, Wignall PB, editors. Understanding Late Devonian and Permian-Triassic biotic and climatic events: towards an integrated approach. Developments in palaeontology and stratigraphy. Amsterdam: Elsevier; 2005. p. 93-180.

Stigall AL, Lieberman BS. Quantitative palaeobiogeography: GIS, phylogenetic biogeographical analysis, and conservation insights. J Biogeogr. 2006;33:2051-60.

Thomas CD, Cameron A, Green RE, Bakkenes M, Beaumont LJ, Collingham YC, Erasmus BFN, Ferreira de Siqueira M, Grainger A,
Hannah L, Hughes L, Huntley B, Van Jaarsveld AS, Midgely GE, Miles L, Ortega-Huerta MA, Peterson AT, Phillips OL, Williams SE. Extinction risk from climate change. Nature. 2004;427:145-8.

Varela S, Lobo JM, Rodríguez J, Batra P. Were the Late Pleistocene climatic changes responsible for the disappearance of the European spotted hyena populations? Hindcasting a species geographic distribution across time. Quat Sci Rev. 2010;29:2027-35.

Vermeij G. Biogeography and adaptation. Cambridge: Harvard University Press; 1978.

Voris HK. Maps of Pleistocene sea levels in Southeast Asia: shorelines, river systems and time durations. J Biogeogr. 2000;27:1153-67.

Walls BJ, Stigall AL. Analyzing niche stability and biogeography of Late Ordovician brachiopod species using ecological niche modeling. Palaeogeogr Palaeoclimatol Palaeoecol. 2011;299:15-29.

Waltari E, Perkins S, Hijmans R, Peterson AT, Nyári Á, Guralnick R. Locating Pleistocene refugia: comparing phylogeographic and ecological niche model predictions. PLoS ONE. 2007;2:e563.

Wang IJ. Recognizing the temporal distinctions between landscape genetics and phylogeography. Mol Ecol. 2010;19:2605-8.

Warren DL, Glor RE, Turelli M. Environmental niche equivalency versus conservatism: quantitative approaches to niche evolution. Evolution. 2008;62:2868-83.

Wells PV. Paleobiogeography of montane islands in the Great Basin since the last glaciopluvial. Ecol Monogr. 1983;53:341-82.

Wiens JJ. Commentary on Losos (2008): niche conservatism déjà vu. Ecol Lett. 2008;11:1004-5. 